\title{
Perilaku Seks Pranikah pada Mahasiswa: Menilik Peran Harga Diri, Komitmen Hubungan, dan Sikap terhadap Perilaku Seks Pranikah
}

\author{
Wahyu Rahardjo', Ajeng Furida Citra², Maizar Saputra ${ }^{3}$, Meta Damariyanti, \\ Aprillia Maharani Ayuningsih ${ }^{5}$ \& Marcia Martha Siahay ${ }^{6}$ \\ 1,2,3,4,5,6Fakultas Psikologi Universitas Gunadarma
}

\begin{abstract}
Some variables such as self-esteem, relationship commitment in dyadic relation commited by the person, and positive attitude, suspected affect premarital sexual behavior. The aim of this study is to measure empirically the influence of self-esteem, relationship commitment, and the attitude of premarital sexual behavior to premarital sexual behavior in college students. This study involved 287 college students as participants. Structural equation model is used to test the hypothesis in this research. The results showed that the empirical model obtained in accordance with the theoretical model, or it has goodness of fit. However, only committed relationship, and attitude of premarital sexual intercourse affect the premarital sexual behavior in college students.
\end{abstract}

Keywords: attitude of premarital sexual behavior; college students; premarital sexual behavior; relationship commitment; self-esteem

\begin{abstract}
Abstrak. Harga diri dan komitmen hubungan pada relasi diadik, serta sikap positif ditengarai menjadi penyebab munculnya perilaku seks pranikah. Tujuan penelitian ini adalah mengetahui secara empiris apakah harga diri, komitmen hubungan, dan sikap terhadap perilaku seks pranikah memengaruhi perilaku seks pranikah pada mahasiswa. Penelitian ini melibatkan 287 orang mahasiswa. Structural Equation Model digunakan untuk menguji hipotesis di dalam penelitian ini. Hasil penelitian menunjukkan bahwa model empirik yang didapatkan sesuai dengan model teoretik yang dibangun. Namun demikian, hanya komitmen hubungan, dan sikap terhadap hubungan seks pranikah yang memengaruhi dilakukannya perilaku seks pranikah pada mahasiswa.
\end{abstract}

Kata kunci: harga diri; komitmen hubungan; mahasiswa; perilaku seks pranikah; sikap terhadap perilaku seks pranikah

Perilaku seks pranikah merupakan permasalahan dan sekaligus fenomena sosial yang kian lazim dijumpai di dalam masyarakat. Pergeseran norma baik-buruk, benar-salah, terutama dalam konteks seksualitas semakin jelas terlihat. Pada kelompok remaja, perilaku seks pranikah semakin dianggap normatif dan tidak

\footnotetext{
${ }^{1}$ Korespondensi mengenai artikel ini dapat melalui: wahyu_rahardjo@yahoo.com
}

menjadi hal yang tabu lagi seperti dahulu. Salah satu bentuk perilaku seks pranikah yang paling permisif adalah dilakukannya hubungan seks. Beberapa studi mengenai perilaku seks mengungkapkan angka di mana hubungan seks pertama kali dilakukan di usia muda, sekitar usia sekolah menengah atas atau di awal masa 
perkuliahan dengan rentang usia 16 hingga 18 tahun (Rahardjo \& Salve, 2014; Rahardjo, 2015). Mahasiswa sendiri telah lama disebutkan sebagai kelompok yang rentan sekaligus juga aktif terlibat dalam perilaku seks pranikah (Uecker, 2015).

Terdapat beberapa hal yang dianggap terkait dengan dilakukannya perilaku seks pranikah. Pertama adalah harga diri. Konsep harga diri pertama kali disebutkan oleh William James pada tahun 1890 yang menjelaskan mengenai esensi positif penghargaan diri yang ditumbuhkan saat individu secara konsisten berusaha meraih banyak hal baik di dalam hidupnya (Zeigler-Hill, 2013). Secara lebih lanjut dijelaskan oleh Mruk (2006) bahwa harga diri merupakan suatu bentuk sikap positif dan pemberian apresiasi dari individu terhadap dirinya sendiri. Orang-orang dengan harga diri positif akan berusaha mengembangkan potensi dan kualitas positif dari diri sendiri, sedangkan orangorang dengan harga diri yang negatif justru terjebak dalam pandangan bahwa dirinya tidak semampu dan sebaik orang lain (Franken, 2002).

Harga diri yang negatif terkadang memicu individu melakukan aktivitas seksual tertentu seperti perilaku seks pranikah untuk mendapatkan kompensasi bahwa dirinya sebetulnya merupakan orang yang berkompeten (Benokraitis, 1996). Artinya, individu dapat terlibat dalam perilaku seks pranikah untuk dapat merasa hebat dan meningkatkan harga dirinya (Unis, Johansson, \& Salstorm, 2015). Temuan Young, Denny, Donnelly, Rodriguwz, dan Hawkins (2002) misalnya, menyebutkan bahwa individu yang tidak terlibat dalam perilaku seks pranikah cenderung memiliki harga diri yang lebih positif. Sementara mereka yang memiliki harga diri negatif memiliki kecenderungan yang lebih besar untuk melakukan seks pranikah, dan bahkan seks berisiko (Ethier et al., 2006). Walaupun demikian, terkadang banyak kelompok individu terlibat di dalam perilaku seks seperti seks pranikah dan berisiko justru dengan keadaan memiliki harga diri yang tidak negatif (Rahardjo, 2013).

Komitmen hubungan juga dianggap memengaruhi perilaku seks pranikah individu. Komitmen hubungan dianggap penting dalam melandasi relasi diadik yang bersifat romantis antar dua individu, terutama pria dan wanita. Komitmen hubungan pada dasarnya adalah niat individu untuk meneruskan hubungan yang dimilikinya bersama pasangan ke arah yang lebih serius (Galinsky \& Sonenstein, 2013). Sementara itu, komitmen biasanya terkait dengan tujuan tertentu. Di dalam riset ini, komitmen hubungan diusung sesuai dengan konsep positif yang diidentifikasi sebagai approach commitment yang mengedepankan usaha untuk menjaga dan meneruskan hubungan yang telah terbina (Strachman \& Gable, 2006). Secara lebih lanjut juga dijelaskan bahwa hubungan yang lebih serius merujuk pada perihal subjektif (orientasi jangka panjang, kelekatan psikologis dengan pasangan), dan karakteristik objektif (status formal hubungan, legalitas hubungan) yang menjadi perhatian dari individu terhadap pasangannya (Galinsky \& Sonenstein, 2013).

Ketika individu memiliki komitmen yang besar dalam melanjutkan hubungan romantis dirinya dengan pasangan ke arah yang lebih serius, maka individu tersebut dapat melakukan pengorbanan dalam banyak hal, termasuk dalam hal seksualitas. Di dalam komitmen hubungan terdapat insentif dan ganjaran dan hal ini terkait dengan usaha mempertahankan hubungan di masa depan (Strachman \& Gable, 2006). Secara lebih lanjut dikatakan 
bahwa demi mempertahankan hubungan dan mendapatkan kepuasan dibutuhkan pengorbanan yang dilakukan individu dalam relasi diadik (Strachman \& Gable, 2006). Salah satu hal yang terkait dengan kepuasan pasangan adalah seksualitas, terutama dalam konteks relasi diadik. Studi Markey dan Markey (2013) menemukan bahwa semakin tinggi komitmen hubungan maka akan semakin tidak permisif perilaku seks individu dengan orang lain selain pasangannya. Artinya, permisivitas seks dilakukan kepada pasangan tetap saja. Individu beranggapan bahwa komitmen merupakan dasar kepercayaan yang sifatnya diadik, sehingga hubungan seks hanya pantas dilakukan terhadap pasangan tetap berlandaskan komitmen (Olmstead, Billen, Conrad, Pasley, \& Fincham, 2013). Sprecher (2002) menyebutkan bahwa komitmen berhubungan berpengaruh terhadap kepuasan akan relasi seks premarital dengan pasangan. Sementara itu temuan berbeda yang juga mendukung temuantemuan tersebut di atas adalah bahwa komitmen hubungan berkorelasi secara negatif dengan sikap terhadap perilaku seks yang dilakukan dengan individu yang bukan pasangan tetapnya (Foster, Shrira, \& Campbell, 2006). Hal ini menjelaskan bahwa aktivitas seks dengan pasangan tetap dapat terjadi dengan berdasarkan komitmen hubungan yang dipersepsikan secara positif oleh individu terhadap pasangannya.

Di lain pihak, cara individu mempersepsikan komitmen hubungan juga memainkan peran penting. Studi Rink, Anastario, dan Fourstar (2015) mengatakan bahwa pria yang menganggap komitmen hubungan antara dirinya dan pasangan tidak terlalu penting cenderung lebih permisif dalam relasi seksual dengan orang lain selain pasangannya. Studi Webster,
Laurenceau, Smith, Mahaffey, Bryan, dan Brunell (2015) memperlihatkan bahwa relasi seks pranikah lebih mudah terjadi ketika komitmen hubungan rendah, terutama ketika usia hubungan diadik yang tercipta masih tergolong baru.

Hal lain yang juga disebut memiliki peran terhadap dilakukannya perilaku seks pranikah adalah sikap yang positif terhadap perilaku seks pranikah itu sendiri. Sikap yang positif terhadap hal tertentu sering dianggap sebagai salah satu pemicu individu untuk terlibat dalam beberapa aktivitas dari hal tersebut. Studi Rahman, Rahman, Ismail, Ibrahim, Ali, Salleh, dan Muda (2012) menyebutkan bahwa sikap yang positif akan perilaku seks pranikah dari remaja akan mendorongnya melakukan perilaku tersebut. Hal ini didukung oleh temuan Mutha et al. (2014) yang menjelaskan bahwa banyak remaja, terutama pria, yang beranggapan bahwa keperawanan tidak harus dijaga hingga jenjang pernikahan dan alat kontrasepsi sepenuhnya tanggung jawab pihak wanita.

Sementara itu, terkait dengan perilaku seks pranikah, Reiss dikenal sebagai salah satu tokoh yang pertama berbicara mengenai perilaku seks pranikah semenjak tahun 1964 hingga sekarang. Menurut Reiss (dalam Crawford \& Popp, 2003), permisivitas individu dalam perilaku seks pranikah tergantung dari sikapnya dalam memandang perilaku seks pranikah itu sendiri. Salah satu teori Reiss yang menarik mengenai sikap terhadap perilaku seks pranikah adalah bahwa pada dasarnya, individu pelaku perilaku seks pranikah dapat digolongkan ke dalam dua kelompok, yaitu (1) permissiveness with affection yang menyatakan bahwa perilaku seks pranikah dibenarkan atas dasar cinta, dan (2) permissiveness without affection yang menjelaskan bahwa perilaku seks pranikah 
dapat dilakukan meskipun tanpa cinta (Crawford \& Popp, 2003).

Pada dasarnya, perilaku seks pranikah merupakan aktivitas seksual yang dilakukan oleh individu dengan orang lain sebelum menikah (Djamba, 2013). Baik pria maupun wanita terlibat di dalam perilaku seks pranikah ini, meskipun keterlibatan pria cenderung lebih dalam dan intensif dibandingkan wanita (Crooks \& Baur, 2013; Zuo, Lou, Gao, Cheng, Niu, \& Zabin, 2012). Banyak individu terlibat dalam perilaku seks pranikah dengan kekasihnya. Namun demikian, beberapa studi juga menyatakan bahwa perilaku seks pranikah dilakukan oleh individu juga dengan teman atau figur yang baru ditemuinya (Soler-Hampejsek, Grant, Mensch, Hewett, \& Rankin, 2013). Di dalam kategori pelaku perilaku seks pranikah, kelompok yang melakukan perilaku seks pranikah hanya dengan kekasihnya disebut sebagai serial monogamist, sedangkan pelaku yang melakukan perilaku seks pranikah dengan berganti-ganti pasangan seks dan tidak selalu dengan pasangan tetapnya disebut dengan sexual adventurer (Conger, 1991).

Berdasarkan penjelasan yang telah dipaparkan sebelumnya, maka hipotesis yang dapat dikembangkan di dalam penelitian ini adalah bahwa harga diri, komitmen hubungan, dan sikap terhadap perilaku seks pranikah dapat menjelaskan terjadinya perilaku seks pranikah pada mahasiswa.

\section{Metode}

Penelitian ini melibatkan 287 orang mahasiswa sebagai partisipan. Partisipan di dalam penelitian ini adalah mahasiswa yang kuliah di universitas $X$ di daerah Jakarta, Bekasi, Cengkareng, Karawaci dan Depok. Seluruh partisipan penelitian adalah mahasiswa lajang yang sedang atau pernah memiliki pasangan, baik yang berkomitmen (seperti kekasih) maupun tidak. Berdasarkan jumlah tersebut, 180 orang di antaranya adalah pria, dan 107 sisanya merupakan partisipan wanita. Usia partisipan sendiri terentang antara 18 hingga 30 tahun $(M=20.63 ; S D=1.36)$.

\section{Alat ukur}

Harga diri adalah suatu bentuk sikap positif dan pemberian apresiasi dari individu terhadap dirinya sendiri (Mruk, 2006). Skala harga diri yang digunakan dalam penelitian ini menggunakan skala milik Rosenberg (1965). Salah satu contoh aitem dalam skala ini adalah "Saya merasa memiliki sejumlah kelebihan". Pilihan jawaban terentang 1-5 mulai dari Sangat Sesuai hingga Sangat Tidak Sesuai. Skala ini awalnya memiliki aitem sejumlah 10 butir. Setelah melalui perhitungan daya diskriminasi aitem terdapat 1 aitem yang gugur. Jumlah aitem yang tersisa adalah 9 butir dengan reliabilitas sebesar 0.804 .

Komitmen hubungan merupakan niat yang dimiliki individu untuk meneruskan hubungan yang dimiliki terhadap pasangannya ke arah yang lebih serius (Galinsky \& Sonenstein, 2013). Skala komitmen hubungan yang digunakan di dalam penelitian ini menggunakan skala milik Galinsky dan Sonenstein (2013). Salah satu contoh aitem dalam skala tersebut adalah "Seberapa besar kecenderungan Anda akan membawa hubungan Anda dengan pasangan menjadi permanen?". Pilihan jawaban untuk skala ini terentang 1-5 mulai dari Sangat Besar hingga Sangat Kecil. Skala ini memiliki aitem sejumlah 4 butir dengan reliabilitas sebesar 0.803 .

Sikap terhadap perilaku seks pranikah adalah pandangan individu tentang variasi kadar boleh tidaknya suatu perilaku seks pranikah itu dilakukan (Reiss dalam Crawford \& Popp, 2003). Pengukuran skala 
sikap terhadap perilaku seks pranikah dalam penelitian ini menggunakan skala milik Reiss (2011), yaitu permissiveness with affection, dan permissiveness without affection. Salah satu contoh aitem dalam skala ini adalah "Saya percaya bahwa hubungan seks pranikah boleh dilakukan dalam suatu hubungan yang tidak berlandaskan rasa cinta". Skala ini memiliki aitem sejumlah 4 butir dengan reliabilitas sebesar 0.919 .

Perilaku seks pranikah adalah aktivitas seksual yang dilakukan individu dengan orang lain sebelum menikah (Djamba, 2013). Pengukuran perilaku seks pranikah di dalam penelitian ini menggunakan konsep perilaku seks pranikah milik Antonovsky (1980) yang mengurutkan perilaku seks pranikah mulai dari tingkatan yang paling rendah atau ringan menuju pada tingkatan yang paling tinggi atau berat. Studi Abraham dan Rahardjo (2015) menggunakan alat ukur ini dan memberikan rentang skor mulai dari 1-18. Partisipan memberikan tanda centang pada perilaku seks pranikah terjauh yang pernah dilakukannya. Misalnya jika perilaku seks pranikah terjauh yang pernah dilakukan adalah "Berpegangan tangan dengan pasangan" maka akan memperoleh skor 2 (karena berada pada tingkat 2 dari level terbawah), atau jika memilih "Berciuman bibir dengan pasangan" akan memperoleh skor 9 karena berada di tingkat 9 dari level terbawah. Skor tertinggi adalah 18 yaitu "Berhubungan badan".

Partisipan dalam penelitian ini telah bersedia secara suka rela untuk mengikuti penelitian ini. Tanda tangan kesediaan telah diberikan di bagian awal kuesioner yang diberikan. Data-data penelitian juga dijaga kerahasiaan oleh tim peneliti sehingga etika penelitian di dalam riset ini telah ditegakkan.

\section{Analisis data}

Teknik analisis data yang digunakan di dalam penelitian ini ada beberapa, yaitu korelasi untuk melihat relasi antar variabel dan sub variabel, kemudian baru dilakukan uji model untuk menegaskan konstelasi variabel yang ada dengan menggunakan structural equation model (SEM) dengan AMOS. Kesesuaian muncul ketika model empirik yang diperoleh memiliki goodness of fit yang baik dengan probabilitas $>0.05$. Analisis tambahan lainnya menggunakan $t$-test terutama untuk membedakan hasil penelitan dari beberapa varibel yang dilibatkan berdasarkan jenis kelamin.

\section{Hasil}

Berdasarkan hasil penelitian diketahui bahwa sebanyak 33 orang $(11.49 \%)$ dari keseluruhan partisipan mengaku sudah terlibat dalam perilaku seks pranikah hingga melakukan hubungan seks atau senggama. Dari 33 orang tersebut, mayoritas adalah mahasiswa pria sebanyak 28 orang $(84.84 \%)$ dan sisanya adalah mahasiswa wanita sebanyak 5 orang (15.15\%). 
Tabel 1.

Korelasi antar variabel untuk keseluruhan partisipan

\begin{tabular}{lcccccrrr}
\hline & 1 & 2 & 3 & 4 & 5 & 6 & Rerata & SD \\
\hline Harga diri & & & & & & & 33.52 & 5.02 \\
Komitmen hubungan & $.211^{* *}$ & & & & & & 16.18 & 2.73 \\
Permissiveness with affection & -.059 & .070 & & & & & 4.03 & 2.16 \\
Permisiveness without affection & -.110 & -.022 & $.759^{* *}$ & & & & 1.71 & 0.99 \\
Perilaku seks pranikah & -.066 & $.130^{*}$ & $.306^{* *}$ & $.259^{* *}$ & & & 9.43 & 5.05 \\
Usia & .051 & $.218^{* *}$ & .115 & .075 & .097 & & 20.63 & 1.36 \\
\hline
\end{tabular}

Keterangan: 1 = Harga diri, $2=$ Komitmen hubungan, $3=$ Permissiveness with affection, $4=$ Permissiveness without affection, $5=$ Perilaku seks pranikah, $6=$ Usia

*signifikan pada $.05,{ }^{* *}$ signifikan pada .01

Harga diri tidak memiliki korelasi yang signifikan dengan semua variabel yang ada, kecuali dengan komitmen hubungan. Sementara itu, hal lain yang tampak berkorelasi secara signifikan dengan perilaku seks pranikah adalah komitmen hubungan, serta sikap terhadap perilaku seks pranikah, baik permissiveness with dan without affection. Komitmen hubungan memiliki korelasi dengan perilaku seks pranikah dan usia. Artinya semakin kuat komitmen hubungan maka akan semakin permisif seks pranikah dilakukan, dan semakin tua usia partisipan maka akan semakin kuat komitmen hubungan dibangun. Usia tidak berkorelasi dengan hampir semua variabel yang ada kecuali komitmen hubungan. Hasil lainnya juga memperlihatkan bahwa semakin positif sikap individu bahwa hubungan seks boleh dilakukan atas dasar cinta, atau tanpa cinta, maka akan semakin permisif perilaku seks pranikah dilakukan. Paparan yang lebih jelas tampak pada Tabel 1.

Sementara itu, hasil penelitian juga memperlihatkan bahwa model empiris yang diperoleh memiliki goodness of fit yang baik dan sesuai dengan model teoretis yang dibangun. Model empiris ini memiliki skor Chi-Square sebesar 5.575 dengan probabilitas sebesar $0.056(p>.05)$. Hasil ini dikatakan baik sebab memiliki skor Chi-
Square kecil dan signifikansi yang lebih besar dari .05. Gambaran yang lebih jelas mengenai model empiris hasil penelitian ini tampak pada Gambar 1.

Berdasarkan hasil penelitian juga tampak bahwa hanya komitmen hubungan dan sikap terhadap perilaku seks pranikah yang memiliki pengaruh terhadap perilaku seks pranikah yang dilakukan mahasiswa. Sementara itu, yang menarik adalah bahwa ternyata harga diri tidak memiliki pengaruh langsung terhadap perilaku seks pranikah, namun memiliki pengaruh langsung terhadap komitmen hubungan. Hasil penelitian juga memperlihatkan bahwa harga diri tidak berpengaruh terhadap sikap partisipan akan perilaku seks pranikah. Guna mendapatkan penjelasan yang lebih kongkrit maka dapat dilihat data-data yang tampak pada Tabel 2 dan Tabel 3.

Hasil penelitian ini juga memperlihatkan bahwa mahasiswa pria memiliki sikap yang lebih positif terhadap perilaku seks pranikah dibandingkan mahasiswa wanita, baik itu permissiveness with affection atau without affection. Secara lebih lanjut juga tampak bahwa mahasiswa pria cenderung lebih bebas dalam melakukan perilaku seks pranikah dibandingkan mahasiswa wanita. Paparan hasil yang lebih jelas tampak pada Tabel 4. 


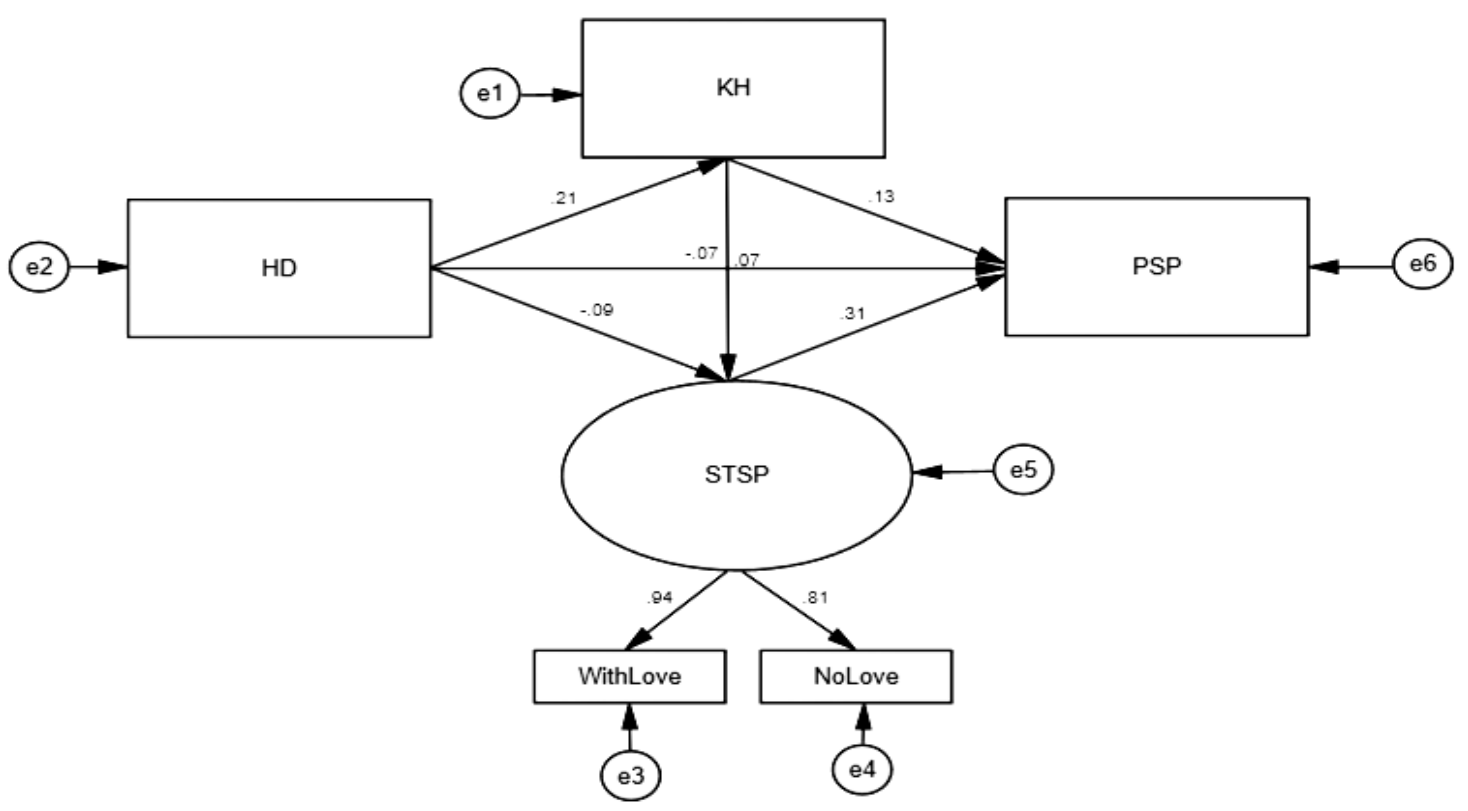

Gambar 1. Model Empiris

Tabel 2

Deskripsi bobot regresi antar variabel untuk signifikansi

\begin{tabular}{lclrcccc}
\hline & & & Estimate & S.E. & C.R. & P & Label \\
\hline KH & $<---$ & HD & .115 & .031 & 3.650 & $* * *$ & \\
Sikap & $<--$ & HD & -.038 & .026 & -1.476 & .140 & \\
Sikap & $<--$ & KH & .055 & .047 & 1.171 & .242 & \\
PSP & $<--$ & HD & -.069 & .058 & -1.195 & .232 & \\
PSP & $<--$ & KH & .237 & .106 & 2.236 & .025 & \\
PSP & $<--$ & Sikap & .777 & .171 & 4.553 & $* * *$ & \\
WithLove & $<---$ & Sikap & 1.000 & & & & \\
NoLove & $<---$ & Sikap & .394 & .058 & 6.855 & $* * *$ & \\
\hline
\end{tabular}

Tabel 3

Bobot regresi terstandardisasi antar variabel

\begin{tabular}{lllc}
\hline & & & Estimate \\
\hline KH & $<---$ & HD & .211 \\
Sikap & $<---$ & HD & -.094 \\
Sikap & $<---$ & KH & .074 \\
PSP & $<---$ & HD & -.069 \\
PSP & $<---$ & KH & .128 \\
PSP & $<---$ & Sikap & .312 \\
WithLove & $<---$ & Sikap & .939 \\
NoLove & $<---$ & Sikap & .808 \\
\hline
\end{tabular}


Hasil penelitian ini juga memperlihatkan terdapat perbedaan sikap positif terhadap perilaku seks pranikah dan perilaku seks pranikah itu sendiri berdasarkan jenis kelamin. Mahasiswa pria memiliki sikap yang lebih positif terhadap perilaku seks pranikah dibandingkan mahasiswa wanita, baik itu permissiveness with affection atau without affection. Secara lebih lanjut juga tampak bahwa mahasiswa pria cenderung lebih bebas dalam melakukan perilaku seks pranikah dibandingkan mahasiswa wanita. Di sisi lain, hasil penelitian juga memperlihatkan tidak adanya perbedaan harga diri dan komitmen hubungan berdasarkan jenis kelamin walaupun mahasiswa wanita memiliki skor harga diri sedikit lebih tinggi dibandingkan mahasiswa pria, dan mahasiswa pria cenderung sedikit lebih kuat membangun komitmen hubungan dibandingkan mahasiswa wanita. Paparan hasil yang lebih jelas tampak pada Tabel 4 .

\section{Diskusi}

Berdasarkan hasil penelitian, secara umum diketahui bahwa konstelasi harga diri, komitmen hubungan, dan sikap terhadap perilaku seks pranikah dapat menjelaskan perilaku seks pranikah yang dilakukan mahasiswa. Namun, hasil yang menarik tampak ketika diperhatikan secara lebih lanjut mengenai pengaruh masing-masing varabel terhadap perilaku seks pranikah.

Harga diri ternyata tidak memiliki pengaruh terhadap dilakukannya perilaku seks pranikah oleh mahasiswa. Hal ini justru menambah variasi dinamika temuan-temuan riset-riset sebelumnya (Rahardjo, 2013; Rahardjo, Saputra, \& Hapsari, 2015). Meskipun ada banyak studi yang menemukan pengaruh harga diri terhadap perilaku seks, namun ada pula beberapa studi yang menemukan hal sebaliknya (Goodson, Buhi, \& Dunsmore, 2006; Maulana \& Rahardjo, 2013; Wheeler, 2010). Temuan Peterson, Buser, dan Westburg (2010) menjelaskan bahwa harga diri bisa saja tidak memiliki pengaruh langsung terhadap perilaku seks yang dilakukan oleh individu. Ada variabelvariabel lain yang dipengaruhi oleh harga diri, sebelum individu menampilkannya dalam bentuk perilaku seks yang permisif. Hal ini mengindikasikan bahwa di dalam penelitian ini, harga diri bukan menjadi hal yang penting dalam mendorong mahasiswa melakukan perilaku seks pranikah. Relasi seksual dengan lawan jenis tidak lagi dianggap sebagai sumber prestise untuk meningkatkan harga diri.

Tabel 4

Komparasi antar variabel berdasarkan jenis kelamin

\begin{tabular}{lcccc}
\hline & Pria & Wanita & t Score & Sig. \\
\hline Harga diri & $33.37(5.11)$ & $33.78(4.87)$ & -0.666 &.$n s$ \\
Komitmen hubungan & $16.39(2.49)$ & $15.82(3.06)$ & 1.704 &.$n s$ \\
Permissiveness with affection & $4.36(2.26)$ & $3.50(1.86)$ & 3.312 & $p<.01$ \\
Permissiveness without affection & $1.89(1.06)$ & $1.40(0.76)$ & 4.134 & $p<.00$ \\
Perilaku seks pranikah & $10.06(5.24)$ & $8.36(4.53)$ & 2.798 & $p<.01$ \\
\hline
\end{tabular}

Sementara itu, komitmen hubungan memiliki pengaruh positif terhadap dilakukannya perilaku seks pranikah pada mahasiswa. Di dalam relasi romantis diadik, individu dapat mempersepsikan komitmen hubungan dengan pasangannya 
dalam tiga hal yang berbeda, yaitu (1) messing atau komitmen hubungan hanya untuk seks, (2) boy-girlfriend yang bersifat lebih intens secara emosi, dan (3) hubbywifey yang sudah meniru karakteristik relasi suami istri (Bauman \& Berman, 2005). Ketiga hal ini penting dalam menentukan pemaknaan relasi yang terjalin di antara mereka, apakah (1) mengandung komitmen kuat untuk masa depan, (2) perlu terbuka dan diketahui umum apa justru harus tertutup dan bersifat rahasia, (3) adanya ekspektasi untuk setia dan melakukan monogami, serta (4) memperlihatkan tingkatan cinta dan kasih sayang (Bauman \& Berman, 2005).

Pada titik ini tampak bahwa persepsi individu terhadap komitmen hubungan yang dijalani dapat menuntun pada perilaku seks pranikah dengan pasangannya. Ketika individu sudah merasa nyaman dan berpikir bahwa dapat melanjutkan hubungan ke tingkat yang lebih serius dengan pasangannya maka kecenderungan untuk terlibat dalam perilaku seks pranikah semakin besar. Studi Bingenheimer, Roche, dan Blake (2017) menyatakan bahwa lamanya durasi hubungan, kedekatan emosional, dan adanya intensi melanjutkan hubungan ke jenjang pernikahan memiliki pengaruh terhadap keterlibatan individu dalam relasi pranikah, termasuk seks pranikah.

Temuan menarik lain disebutkan oleh studi milik Tschann, Selcedo, Soon, Elia, dan Kaneshiro (2017). Studi ini menemukan bahwa remaja memiliki kecenderungan menghindari perilaku seks pranikah lebih kepada takut terinfeksi penyakit menular seksual dibandingkan kehamilan yang tidak diinginkan. Jika dilihat dari sisi permisivitas seks secara monogamis, dapat dipahami terkait persepsi bahwa kekasih atau pasangan tetap dianggap individu yang aman dan bersih sehingga kemungkinan menularkan penyakit menular seksual saat berhubungan seks lebih kecil. Sebagai akibatnya, berdasarkan komitmen hubungan yang kuat dan persepsi bahwa kemungkinan tertular penyakit menular seksual relatif kecil, maka individu cenderung lebih mudah terlibat perilaku seks pranikah dengan pasangan tetap.

Di dalam relasi romantis terdapat suatu persepsi bahwa hubungan yang terjalin akan terasa lebih memuaskan jika melibatkan intimasi fisik dan seksual, komunikasi yang baik, dukungan emosional yang kuat, dan kebersamaan (Rostosky, Welsh, Kawaguchi, \& Galliher, 1999). Secara lebih lanjut juga dijelaskan pula oleh Rostosky, Welsh, Kawaguchi, dan Galliher (1999) bahwa karakteristikkarakteristik tersebut sangat lazim ditemui pada pasangan yang sudah menikah. Namun demikian, pasangan yang belum menikah juga mengadopsi prinsip tersebut dengan perbedaan yang cukup mendasar, yaitu komitmen hubungan yang dimiliki tidak sekuat komitmen hubungan pasangan yang menikah.

Temuan bahwa komitmen hubungan memiliki pengaruh positif terhadap perilaku seks pranikah dalam studi ini cukup menarik mengingat studi lain juga memperlihatkan temuan bahwa rendahnya komitmen hubungan memiliki pengaruh yang cukup kuat bagi individu untuk terlibat dalam perilaku seks pranikah dengan orang yang bukan pasangan tetapnya (Mattingly, Clark, Weidler, Bullock, Hackatorn, \& Blankmayer, 2011).

Temuan lain dalam studi ini juga memperlihatkan pengaruh sikap terhadap perilaku seks pranikah pada perilaku seks pranikah itu sendiri. Secara umum, hal ini dapat dianggap sebagai akibat dari globalisasi. Studi Cheng, Lou, Gao, Emerson, dan Zabin (2012) menemukan 
bahwa globalisasi yang membawa akibat pada pergeseran perspektif norma terhadap perilaku tertentu menyebabkan remaja lajang mengembangkan sikap yang lebih positif terhadap perilaku seks pranikah.

Studi Rahman et al. (2012) bukan hanya menemukan bahwa sikap yang positif terhadap perilaku seks pranikah yang diyakini remaja dapat membawa mereka melakukan perilaku seks pranikah, tetapi juga mengungkap bahwa remaja pria memang cenderung memiliki sikap terhadap perilaku seks pranikah yang lebih positif dibandingkan remaja wanita. Temuan Olmstead, et al. (2013) menyebutkan bahwa pada dasarnya, keterkaitan antara komitmen hubungan, sikap positif terhadap perilaku seks, dan perilaku seks itu sendiri dapat menggolongkan pria ke dalam tiga kelompok, yaitu (1) committers atau kelompok yang memegang teguh komitmen hubungan dengan pasangannya, (2) flexibles atau kelompok yang berada di wilayah abu-abu di mana perilaku seks dilakukan sebagai bentuk pemaknaan komitmen dan perasaan yang mendalam, atau bisa juga dilakukan tanpa keterlibatan komitmen sama sekali, dan (3) recreationers atau kelompok yang tidak memegang komitmen hubungan dan terlibat dalam banyak perilaku seks diadik untuk bersenang-senang.

Temuan lebih lanjut yang mendukung hasil studi ini merupakan temuan riset milik Olmstead, Anders, dan Conrad (2016). Riset ini menegaskan bahwa proporsi wanita di kelompok commiters lebih sedikit dibandingkan pria. Sementara itu, proporsi pria di kelompok flexibles dan recreationers lebih banyak dibandingkan wanita. Sprecher, Treger, dan Sakaluk (2013) di dalam studi kohortnya menyebutkan bahwa meskipun terjadi penurunan angka perbedaan sikap positif terhadap perilaku seks pranikah antara pria dan wanita, namun tetap saja ada perbedaan angkat temuan yang signifikan secara statistik di mana pria memiliki sikap terhadap perilaku seks pranikah secara lebih positif dibandingkan wanita.

\section{Kesimpulan}

Komitmen hubungan memiliki pengaruh terhadap dilakukannya perilaku seks pranikah, walaupun tidak sebesar pengaruh yang diberikan sikap terhadap perilaku seks pranikah. Sikap positif terhadap perilaku seks pranikah tetap menjadi salah satu faktor pendorong utama dilakukannya perilaku seks pranikah. Temuan ini kian menegaskan banyak temuan studi-studi sebelumnya. Sementara itu, tidak adanya pengaruh harga diri memperlihatkan bahwa variabel ini bersifat sangat dinamis dalam studi-studi terkait perilaku seks dan tetap berharga untuk dilibatkan dalam studi-studi perilaku seks berikutnya dengan konteks permasalahan atau partisipan yang berbeda.

\section{Saran}

Ada beberapa saran yang dapat dikemukakan terkait hasil studi ini. Pertama, mempertimbangkan peran variabel sosial budaya seperti standar ganda seksual, atau variabel yang terkait dengan proses perkembangan individu seperti sejarah perilaku seks individu. Kedua, memperluas cakupan demografis partisipan ke kota-kota kecil yang memiliki kemajuan pembangunan tidak sepesat di kota-kota besar. Ketiga, memberdayakan teman sebaya sebagai agen perubahan sosial terutama dalam hal sosialisasi konsekuensi negatif perilaku seks pranikah. Hal ini mungkin saja lebih efektif dalam 
menumbuhkan sikap negatif terhadap perilaku seks pranikah melalui kelompok yang memang memiliki kelekatan erat pada individu di masa remaja akhir.

\section{Kepustakaan}

Abraham, J., \& Rahardjo, W. (2015). Psychopathy, sexual values dimensions, and premarital sexual behavior among urban unmarried adolescents. Procedia Social and Behavioral Sciences, 165, 2-11. doi: 10.1016/ j.sbspro. 2014.12.598.

Antonovsky, H. S. (1980). Adolescent sexuality. Lexington: Lexintong Books.

Bauman, L. J., \& Berman, R. (2005). Adolescent relationships and condom use: Trust, love and commitment. AIDS and Behavior, 9(2), 211-222. doi: 10. 1007/s10461-005-3902-2

Benokraitis, N. J. (1996). Marriages and families: Changes, choices and constraints (second edition). New Jersey: Prentice Hall.

Bingenheimer, J. B., Roche, K. M., \& Blake, S. M. (2017). Family adult awareness of adolescents' premarital romantic and sexual relationships in Ghana. Youth $\mathcal{E}$ Society, 49(3), 341-368. doi: 10.1177/ 0044118X15581168

Cheng, Y., Lou, C., Gao, E., Emerson, M. R., \& Zabin, L. S. (2012). The relationship between external contact and unmarried adolescents' and young adults' traditional beliefs in three East Asia cities: A cross-sectional analysis. Journal of Adolescent Health, 50(3), S4S11. doi: 10.1016/ j.jadohealth. 2011. 12.011

Conger, J. J. (1991). Adolescence and youth. New York: Harper Collins Publisher.

Crawford, M., \& Popp, D. (2003). Sexual double standards: A review and methodological critique of two decades of research. The Journal of Sex Research, 40(1), 13-37. doi: 10.1080/ 002244 90309552163.

Crooks, R., \& Baur, K. (2013). Our sexuality (12 ${ }^{\text {th }}$ edition). Belmont: Wadsworth.

Djamba, Y. K. (2013). Sexual practices in Africa. Dalam A. K. Baumle (Ed.), International handbook on the demography of sexuality. (pp.91-106). Dordrecht: Springer.

Ethier, A. K., Kershaw., T. S., Lewis, J. B., Milan, S., Niccolai, L. M., \& Ickovics, J. R. (2006). Self esteem, emotional distress and sexual behavior among adolescent females: interrelationship and temporal effects. Journal of Adolescent Health, 38(3), 268-274. doi: 10. 1016/j.jadohealth.2004.12.010.

Foster, J. D., Shrira, I., \& Campbell, W. K. (2006). Theoretical models of narcissism, sexuality, and relationship commitment. Journal of Social and Personal Relationships, 23(3), 367-386. doi: $10.1177 / 0265407506064204$

Franken, R. E. (2002). Human motivation (5 $5^{\text {th }}$ edition). Belmont: Wardsworth.

Galinsky, A. M., \& Sonenstein, F. L. (2013). Relationship commitment, perceived equity, and sexual enjoyment among young adults in the United States. Archives of Sexual Behavior, 42(1), 93-104. doi: 10.1007/s10508-012-0003-y.

Goodson, P., Buhi, E. R., \& Dunsmore, S. C. (2006). Self-esteem and adolescent sexual behaviors, attitudes, and intentions: A systematic review. Journal of Adolescent Health, 38, 310-319. doi: 10. 1016/j.jadohealth.2005.05.026.

Markey, P., \& Markey, C. (2013). Sociosexuality and relationship commitment among lesbian couples. Journal of Research in Personality, 47(4), 282-285. doi: 10.1016/j.jrp.2013.02. 002 
Mattingly, B. A., Clark, E. M., Weidler, D. J., Bullock, M., Hackatorn, J., \& Blankmeyer, K. (2011). Sociosexual orientation, commitment, and infidelity: A mediation analysis. The Journal of Social Psychology, 151(3), 222226. doi: 10.108000224540903536162.

Maulana, A., \& Rahardjo, W. (2013). Harga diri dan perilaku seks pranikah pada mahasiswa penggemar film porno yang tinggal di tempat kost. Makalah (tidak diterbitkan). Dipresentasikan pada Temu Ilmiah Nasional 3 di Fakultas Psikologi Universitas Tarumanagara.

Mruk, C. J. (2006). Self-esteem research, theory, and practice: Toward a positive psychology of self-esteem (3 ${ }^{\text {rd }}$ edition). New York: Springer Publishing Company.

Mutha, A. S., Mutha, S. A., Baghel, P. J., Patil, R. J., Bhagat, S. B., Patel, S. B., \& Watsa, M. C. (2014). A knowledge, attitudes and practices survey regarding sex, contraception and sexually transmitted diseases among commerce college students in Mumbai. Journal of Clinical and Diagnostic Research, 8(8), HC14-HC18. doi: 10. 7860/JCDR/2014/9967.4684

Olmstead, S. B., Billen, R. M., Conrad, K. A., Pasley, K., \& Fincham, S. D. (2013). Sex, commitment, and casual sex relationships among college men: A mixed-methods analysis. Archives of Sexual Behavior, 42, 561-572. doi: 10. 1007/s10508-012-0047-z

Olmstead, S. B., Anders, K. M., \& Conrad, K. A. (2016). Meanings for sex and commitment among first semester college men and women: A mixedmethod analysis. Archives of Sexual Behavior, 5, 1-12. doi: 10.1007/s10508016-0777-4
Peterson, C. H., Buser, T. J., \& Westburg, N. G. (2010). Effects of familial attachment, social support, involvement, and self-esteem on youth substance use and sexual rist taking. The Family Journal: Counseling and Therapy for Couples and Families, 18(4), 369-376. doi: 10.1177/ 10664807103 80546

Rahardjo, W. (2013). Model perilaku seks berisiko pada pria. (Disertasi tidak diterbitkan). Yogyakarta: Fakultas Psikologi Universitas Gadjah Mada.

Rahardjo, W. (2015). Peran harga diri dan perilaku seksual daring terhadap usia hubungan seks pertama kali dan jumlah pasangan seks pada pria heteroseksual lajang. Makalah. Dipresentasikan pada Seminar Nasional "Selamatkan Generasi Bangsa dengan Membentuk Karakter Berbasis Kearifan Lokal" yang diselenggarakan di Hotel Aston Solo oleh Fakultas Psikologi Universitas Muhammadiyah Surakarta, Juni 2015.

Rahardjo, W., \& Salve, H. R. (2014). Hubungan orang tua - anak, kelekatan teman sebaya, dan usia melakukan hubungan seks pertama kali pada mahasiswa. Makalah. Dipresentasikan pada Seminar Nasional Ketahanan Nasional sebagai Aset Bangsa di Fakultas Psikologi Universitas Merdeka Malang, Jawa Timur tanggal 21 Juni 2014.

Rahardjo, W., Saputra, M., \& Hapsari, I. (2015). Harga diri, sexting dan jumlah pasangan seks yang dimiliki pria lajang pelaku perilaku seks berisiko. Jurnal Psikologi, 42(2), 101-114. doi: 10.22146/jpsi.7172

Rahman, A. A., Rahman, R. A., Ismail, S. B., Ibrahim, M. I., Ali, S. H., Salleh, H., \& Muda, W. A. M. W. (2012). Factors 
associated with attitude toward premarital sexual activities among school-going adolescents in Kelantan, Malaysia. Asia-Pasific Journal of Public Health, 20, 1-8. doi: 10.1177/ 1010539512449856.

Reiss, I. L. (2011). Reiss premarital sexual permissiveness scale (short form). In T. D. Fisher, C. M. Davis, W. L. Yarber \& S. L. Davis (Eds.), Handbook of sexualityrelated measures (third edition). (pp.509510). New York: Routledge.

Rink, E., Anastario, M. P., \& Fourstar, K. (2015). Perceived level of relationship commitment, sexual risk taking and condom use among American Indian men. Journal of Immigrant Minority Health, 17(4), 1078-1085. doi: 10.1007/s10903-014-0058-z.

Rosenberg, M. (1965). Society and the adolescent self-image. New Jersey: Princeton University Press.

Rostosky, S. S., Welsh, D. P., Kawaguchi, M. C., \& Galliher, R. V. (1999). Commitment and sexual behaviors in adolescent dating relationships. In J. M. Adams \& W. H. Jones (Eds.), Handbook of interpersonal commitment and relationship stability. (pp. 323-338). New York: Springer.

Sprecher, S. (2002). Sexual satisfaction in premarital relationships: Associations with satisfaction, love, commitment, and stability. The Journal of Sex Research, 39(3), 190-196. doi: 10.1080/00224490209552141.

Sprecher, S., Treger, S., \& Sakaluk, J. K. (2013). Premarital sexual standards and sociosexuality: Gender, ethnicity, and cohort differences. Archives of Sexual Behavior, 42(8), 1395-1405. doi: 10.1007/s10508-013-0145-6

Strachman, A., \& Gable, S. L. (2006). Approach and avoidance relationship commitment. Motivation and Emotion, 30, 117-126. doi:10.1007/s11031-0069026-9.

Soler-Hampejsek, E., Grant, M. J., Mensch, B. S., Hewett, P. C., \& Rankin, J. (2013). The effect of school status and academic skills on the reporting of premarital sexual behavior: Evidence from a longitudinal study in Rural Malawi. Journal of Adolescent Health, 53(2), 228-234. doi: 10.1016/ j.jadohealth. 2013.03.008.

Tschann, M, Salcedo, J., Soon, R., Elia, J., \& Kaneshiro, B. (2017). Norms, attitudes, and preferences: Responses to a survey of teens about sexually transmitted infection and pregnancy prevention. Journal of Pediatric and Adolescent Gynecology, 30(1), 29-34. doi: 10.1016/j.jpag.2016.09.003

Uecker, J. E. (2015). Social context and social intercourse among first-year students at selective colleges and universities in the United States. Social Science Research, 52, 59-71. doi: 10.1016/j.ssresearch.2015.01.005

Unis, B., Johansson, I., \& Sallstorm, C. (2015). Rural high school students' sexual behavior and self esteem. Open Journal of Nursing, 5, 24-35. doi: 10.4236/ojn.2015.51004

Webster, G. D., Laurenceau, J. P., Smith, C. V., Mahaffey, A. L., Bryan, A. D., \& Brunel, A. B. (2015). An investment model of sociosexuality, relationship satisfaction, and commitment: Evidence from dating, engaged, and newlywed couples. Journal of Research in Personality, 55, 112-126. doi: 10. 1016/j.jrp.2015.02.004.

Wheeler, S. B. (2010). Effects of self-esteem and academic performance on adolescent decision-making: An examination of early sexual intercourse 
and illegal substance use. Journal of Adolescent Health, 47, 582-499. doi: 10. 1016/j.jadohealth.2010.04.009.

Young, M., Denny, G., Donnelly, J., Rodriguez, M., \& Hawkins, M. (2002). Area specific self-esteem and sexual behavior among Hispanic middle school students. American Journal of Health Education, 33(6), 344-349. doi: 10. 1080/ 19325037.2002.10604758
Zeigler-Hill, V. (2013). The importance of self-esteem. In V. Zeigler-Hill (Ed.), Self-esteem. (pp.1-10). New York: Psychology Press.

Zuo, X., Lou, C., Gao, E., Cheng, Y., Niu, H., \& Zabin, L. S. (2012). Gender differences in adolescent premarital sexual permissiveness in three Asian cities: Effects of gender-role attitudes. Journal of Adolescent Health, 50, S18-S25. doi: 10.1016/j.jadohealth.2011.12.001. 